\title{
What do archaeal and eukaryotic histidine kinases sense?
}

\section{[version 1; peer review: 3 approved]}

\author{
Nicolas Papon ${ }^{1}$, Ann M. Stock (iD) 2 \\ ${ }^{1}$ Groupe d'Etude des Interactions Hôte-Pathogène (GEIHP, EA 3142), SFR ICAT 4208, UNIV Angers, UNIV Brest, Angers, France \\ ${ }^{2}$ Department of Biochemistry and Molecular Biology, Center for Advanced Biotechnology and Medicine, Rutgers-Robert Wood \\ Johnson Medical School, Piscataway, NJ, 08854, USA
}

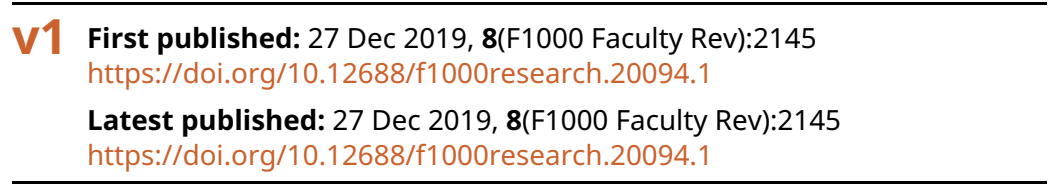

\section{Abstract}

Signal transduction systems configured around a core phosphotransfer step between a histidine kinase and a cognate response regulator protein occur in organisms from all domains of life. These systems, termed two-component systems, constitute the majority of multi-component signaling pathways in Bacteria but are less prevalent in Archaea and Eukarya. The core signaling domains are modular, allowing versatility in configuration of components into single-step phosphotransfer and multi-step phosphorelay pathways, the former being predominant in bacteria and the latter in eukaryotes. Two-component systems regulate key cellular regulatory processes that provide adaptive responses to environmental stimuli and are of interest for the development of antimicrobial therapeutics, biotechnology applications, and biosensor engineering. In bacteria, two-component systems have been found to mediate responses to an extremely broad array of extracellular and intracellular chemical and physical stimuli, whereas in archaea and eukaryotes, the use of twocomponent systems is more limited. This review summarizes recent advances in exploring the repertoire of sensor histidine kinases in the Archaea and Eukarya domains of life.

\section{Keywords}

two-component system, histidine kinase, sensor, evolution, signal transduction, phosphorylation

\section{Open Peer Review}

$\begin{array}{rcc}\text { Approval Status } & \checkmark \checkmark \\ 1 & 2 & 3\end{array}$

version 1

27 Dec 2019

Faculty Reviews are review articles written by the prestigious Members of Faculty Opinions. The articles are commissioned and peer reviewed before publication to ensure that the final, published version is comprehensive and accessible. The reviewers who approved the final version are listed with their names and affiliations.

1. Wei Qian, Institute of Microbiology, Chinese Academy of Sciences, Beijing, China

2. Jeffrey J. Tabor, Rice University, Houston, USA

3. Sean Crosson, Michigan State University, East Lansing, USA

Any comments on the article can be found at the end of the article. 
Corresponding authors: Nicolas Papon (nicolas.papon@univ-angers.fr), Ann M. Stock (stock@cabm.rutgers.edu)

Author roles: Papon N: Conceptualization, Writing - Original Draft Preparation, Writing - Review \& Editing; Stock AM:

Conceptualization, Writing - Original Draft Preparation, Writing - Review \& Editing

Competing interests: No competing interests were disclosed.

Grant information: AMS was supported by National Institutes of Health grant R35 GM131727

The funders had no role in study design, data collection and analysis, decision to publish, or preparation of the manuscript.

Copyright: ๑ 2019 Papon N and Stock AM. This is an open access article distributed under the terms of the Creative Commons

Attribution License, which permits unrestricted use, distribution, and reproduction in any medium, provided the original work is properly cited.

How to cite this article: Papon $\mathrm{N}$ and Stock $\mathrm{AM}$. What do archaeal and eukaryotic histidine kinases sense? [version 1; peer review: 3 approved] F1000Research 2019, 8(F1000 Faculty Rev):2145 https://doi.org/10.12688/f1000research.20094.1

First published: 27 Dec 2019, 8(F1000 Faculty Rev):2145 https://doi.org/10.12688/f1000research.20094.1 


\section{Introduction}

Protein phosphorylation is one of the most extensively used modifications in signal transduction pathways in both prokaryotic and eukaryotic cells. Prominent families of enzymes that perform protein phosphorylation encompass serine/threonine kinases, tyrosine kinases, and histidine kinases (HKs). Although HKs dominate prokaryotic signaling pathways, they are less prevalent in eukaryotes ${ }^{1,2}$. A distinct class of mammalian HKs, specifically nucleoside diphosphate kinases, function together with associated phosphatases to catalyze reversible histidine phosphorylation of proteins, and the roles of such modifications in cellular regulation are beginning to be uncovered ${ }^{3-7}$. However, the large family of HKs that is prevalent in prokaryotes is absent from animals. Historically, a small number of eukaryotic HKs have been studied in plants, yeasts, filamentous fungi, and slime molds. Recent studies have expanded the characterization of HKs in other eukaryotic lineages and archaea, allowing a broader assessment of the types of signaling systems mediated by HKs and their phylogenetic distribution and evolution. HKs are central to regulatory systems that impact agriculture, the environment, and both beneficial and pathogenic interactions of microbes with humans and other animals. Their great diversity, versatility, and broad distribution, as well as the specificity of HK communication with cognate downstream components, make them attractive targets for therapeutics ${ }^{8-12}$ and biotechnological interventions ${ }^{13-16}$ and also as building blocks for engineered biosensor systems ${ }^{17-21}$.

HKs occur primarily within pathways designated as "twocomponent systems" (TCSs) ${ }^{22,23}$ (Figure 1). TCSs correspond to cell signaling circuitries that permit organisms, either unicellular or multicellular, to sense and respond to a broad palette of environmental changes. From a mechanistic perspective, these transduction pathways rely on the sequential transfer of a phosphoryl group on conserved histidine or aspartate residues (or both) located in several families of proteins. In prokaryotes, TCSs are usually restricted to communication between two functional modules (that is, phosphoryl transfer between HKs and response regulators [RRs]) (Figure 1A). In canonical prokaryotic systems, the perception of a stimulus regulates the opposing autophosphorylation and phosphatase activities of the HK, which thus acts as a primary sensor. The phosphoryl group is transferred to a RR that effects the response. In many prokaryotic TCSs $(\sim 65 \%)$, the RR is a transcription factor that directly regulates the expression of a set of genes required for an adaptive response to the stimulus ${ }^{24,25}$.

In contrast, classic eukaryotic TCSs usually involve more complex multi-step phosphorelays ${ }^{26,27}$ but, as in prokaryotes, also begin by the perception of an input stimulus by a sensor HK, specifically a "hybrid" HK (Figure 1B). Signal perception modulates autophosphorylation of the $\mathrm{HK}$ on a conserved histidine residue prior to transfer to a conserved aspartate residue in a C-terminal domain of the HK. The phosphoryl group is then transmitted to a conserved histidine residue of a small shuttle protein of about 150 amino acid residues (histidine-containing phosphotransfer protein, HPt; $\mathrm{Pfam}^{28}$ ID PF01627) and finally to a conserved aspartate residue of a protein belonging to the RR family. The phosphorylation state of this RR orchestrates subsequent molecular events underlying the response to the input signal, either by directly regulating transcription or by interfacing with other conventional eukaryotic

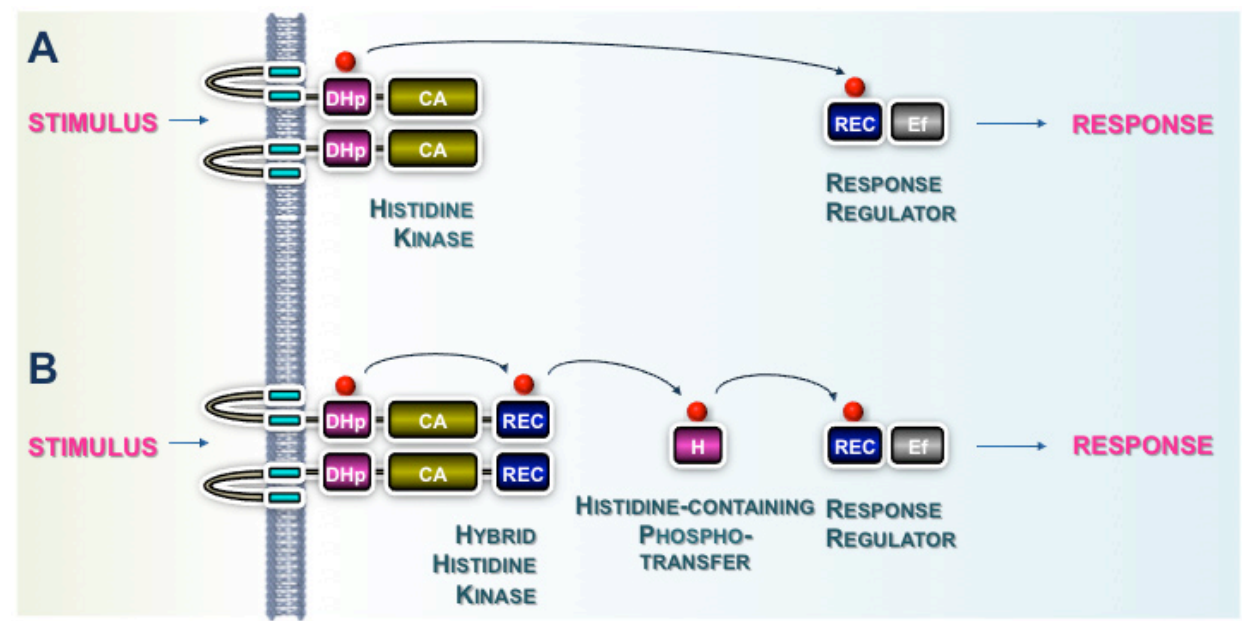

Figure 1. Two-component system phosphotransfer schemes. (A) A typical phosphotransfer pathway, as is usually found in prokaryotes. The perception of a stimulus by extracytoplasmic domains of the histidine kinase (HK) regulates its activities. The HK autophosphorylates at a conserved histidine residue $(\mathrm{H})$ using ATP bound to the catalytic ATPase domain (containing conserved motifs N, G1, F, and G2). The phosphoryl group $(P)$ is transferred to a conserved aspartate residue (D) located within the cognate response regulator (RR). (B) An example of a multi-step phosphorelay, as often occurs in eukaryotes. The HK is termed "hybrid" because an additional aspartate-containing domain is fused to the ATPase domain. The phosphorelay involves multiple phosphoryl transfer steps. The first is an intramolecular transfer between the conserved histidine $(\mathrm{H})$ and a conserved aspartate residue (D) located within the C terminus of the sensor HK. Subsequently, the phosphoryl group is transferred to a histidine-containing phosphotransfer protein and finally to a cognate RR. Conserved domains of the two-component system (TCS) proteins are shown in green, gold, and blue. Variable sensor domains of the HK and effector domains (Ef) of the RR that adapt the systems to a wide range of input stimuli and output responses are shown in gray. 
signaling strategies such as mitogen-activated protein kinase cascades or cAMP signaling that control the output response. As a result of specific evolutionary paths in which the various eukaryotic lineages have engaged, the canonical TCS pathway described above appears to have degenerated in several clades in which these cell signaling systems have been described.

The canonical structure of HKs is composed of a set of variable and conserved domains ${ }^{29}$ (Figure 2) that couple the sensing of a wide range of chemical or physical stimuli to the phosphotransfer pathway. Here, we review recent advances in the characterization of HKs in archaea and eukaryotes with an emphasis on what they sense and what the main output processes that this prominent family of sensors regulates are. Some emerging trends dealing with their distribution among the various lineages and their evolution are also considered.

\section{HKs in Archaea}

TCSs are relatively rare in archaea and are not uniformly distributed across archaeal phyla ${ }^{30-32}$. The majority of archaeal TCSs have been identified in Euryarchaeota and Thaumarchaeota, but the possibility exists that greater distribution will be revealed as more archaeal genomes are sequenced. Several notable features differ between archaeal and bacterial $\mathrm{TCSs}^{32}$. Archaeal genomes typically contain fewer TCSs and typically have an HK-to-RR ratio greater than 1, suggesting that multiple HKs might feed into a single RR or that HKs might be paired with alternative downstream components. Unlike bacterial HKs that are mostly transmembrane proteins (estimated at 73 to $88 \%$ ), $62 \%$ of archaeal HKs lack identifiable transmembrane regions and are presumed to be cytoplasmic. Interestingly, previous analyses of bacterial and archaeal chemoreceptors have shown a similar bias for cytoplasmic sensing in archaea $^{33}$. Correspondingly, although extracellular Cache-calcium channels and chemotaxis receptors, also previously identified as PAS (period circadian protein-Aryl hydrocarbon receptor nuclear translocator protein-single-minded protein), PAS-like, PhoQ-DcuS-CitA (PDC), PDC-like, and PDC/PAS ${ }^{34-36}$ domains-are the most abundant sensor domains in bacterial HKs, intracellular PAS and GAF (cGMP-specific phosphodiesterases-adenylyl cyclasesFhlA) domains are predominant in archaeal HKs, and $72 \%$ of them contain one or more PAS or GAF domains (or both) ${ }^{32}$. In addition to Cache domains, less populated sensor domain families include MEDS (methanogen/methylotroph, DcmR sensory domain; Pfam ID PF14417), PocR (Pfam ID PF10114, HisKA_7TM (Pfam ID PF16927), and HisKA_4TM (Pfam ID PF16926), the latter being distinct to haloarchaea.

Other than chemotaxis ${ }^{37,38}$ and phototaxis ${ }^{39,40}$ systems, few archaeal TCS pathways have been characterized. Two recently studied systems, similar to conventional TCSs, are the LtrK/ LtrR TCS that mediates temperature-dependent gene regulation in an Antarctic methanogen ${ }^{41}$ and a TCS comprised of HK FilI and RRs FilR1 and FilR2 that regulates transcription of methanogenesis genes in response to unknown stimuli in Methanosaeta harundinacea ${ }^{42}$. Two less conventional HKs, each containing multiple PAS and GAF domains, have recently been characterized from Methanosarcina acetivorans ${ }^{43,44}$. MsmS is a heme-based redox/dimethyl sulfide sensor, and $\mathrm{RdmS}$ is a thiol-based redox sensor; both regulate genes involved in methyl sulfide metabolism. Autophosphorylation of both HKs is redox-dependent, although neither contains a phosphorylatable histidine and MsmS phosphorylation has been shown to occur at tyrosine. Furthermore, the identified downstream regulators lack RR receiver (REC) domains, indicating that these HKs function in signaling systems distinct from TCSs.

The outputs of archaeal TCSs are currently as unexplored as the inputs. However, unlike archaeal HK sensor domains that belong to families common to bacterial counterparts such as PAS and GAF, albeit with different prevalence, archaeal RR effector domains do not correspond to the major families found in bacterial RRs ${ }^{32}$. Most notable is the low abundance of recognizable DNA-binding domains $(6 \%)$. The fraction of archaeal RRs consisting solely of REC domains (39\%) is almost double that observed in bacteria. Other major families

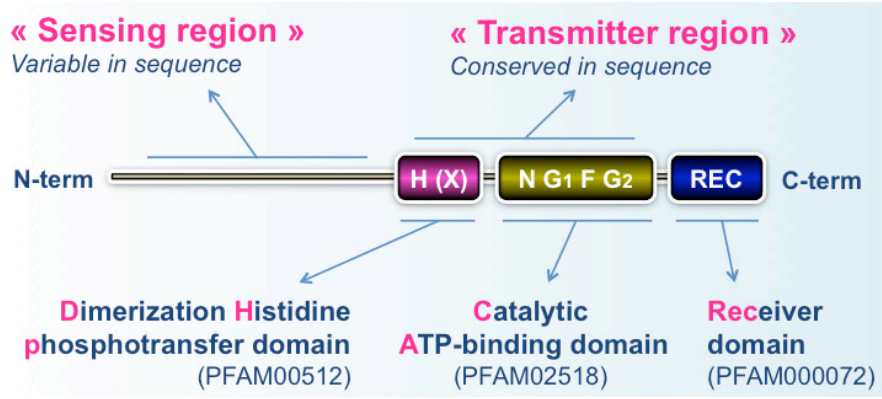

Figure 2. Canonical structure of histidine kinases (HKs). HKs are composed of a set of variable and conserved domains. The first region corresponds to a highly variable, typically N-terminal sequence that determines which stimulus is perceived by the HK. This region is referred to as the "sensing domain". The central "transmitter region" is composed of two conserved domains: a dimerization histidine phosphotransfer (DHp) domain (His kinase A, HisKA; Pfam ID PF00512, or other subfamily such as HisKA_2, HisKa_3) and a catalytic ATP-binding (CA) domain (histidine kinase-like ATPase catalytic, HATPase_C; Pfam ID PF02518). The DHp domain includes an H-box, usually containing the phosphorylatable histidine, and an X-box. The CA subdomain includes four distinct sequence motifs: the N-, G1-, F-, and G2-boxes. In contrast to prokaryotic HKs, most eukaryotic HKs contain an additional C-terminal RR receiver (REC) domain (Response_reg; Pfam ID PF00072) that includes a phosphorylatable aspartate residue. Thus, eukaryotic HKs are generally called "hybrid HKs"26. 
include dimerization histidine phosphotransfer (DHp) domains (that is, HisKA), PAS ${ }_{n}$ GAF, PAS-GAF, chemotaxis CheB, HalX (with a predicted helix-turn-helix, possibly DNA-binding), and various enzyme domains as well as several novel domain families.

\section{HKs in Eukarya}

Historically, plants were the first eukaryotic kingdom in which HKs were identified and functions of plant HKs have been informed primarily in the last decades by descriptions of TCSs in the model plant Arabidopsis thaliana ${ }^{45-48}$. Along with these pioneering works in plants, some groups of HKs were progressively characterized in other eukaryotic lineages such as Amoebozoa (mainly the slime mold Dictyostelium discoideum) ${ }^{49-52}$ and Fungi (mainly the yeasts Saccharomyces cerevisiae, Candida albicans, and Cryptococcus neoformans and the filamentous fungi Neurospora crassa and Aspergillus fumigatus) $)^{53,54}$. To date, what the biological roles in the remaining eukaryotic phyla are and what HKs sense are still largely obscure ${ }^{55}$. In the following section, we will briefly describe major groups of eukaryotic HKs, notably their structures, phylogenetic distribution, and their roles in hormone perception, stress adaptation, and developmental programs.

The first group of eukaryotic HKs characterized is now well documented to be dedicated to the perception of and response to the plant hormone (phytohormone) ethylene (Table 1) ${ }^{56}$. Ethylene is a gas that regulates many aspects of plant development such as seed germination, leaf senescence, and fruit ripening but also orchestrates plant defenses to pathogens (viruses, protists, bacteria, fungi, worms, and insects $)^{57}$. From a structural point of view, it is important to highlight that ethylene sensing through HK ethylene receptors (ETRs) occurs by the interaction of the gaseous molecule with the ethylene-binding domain (EtBD) located at the $\mathrm{N}$ terminus of the receptors. The EtBD consists of three hydrophobic transmembrane helices (indicated by three asterisks in Table 1) containing seven conserved amino acids required for ethylene binding ${ }^{58}$. For a long time, typical ETRs were believed to be restricted to land plants and cyanobacteria ${ }^{59}$. Surprisingly, these considerations have now been called into question through the identification in recent years of genes encoding ETR homologs in many other eukaryotic lineages, including green and brown algae, free-living amoebae, photosynthetic diatoms, zooxanthellae that are symbiotically associated with coral reefs, early diverging fungi, filamentous marine protists (Labyrinthulomycetes), and even the unicellular model animal ancestor Capsaspora owczarzaki ${ }^{60-64}$. Interestingly, an EtDB coupled to a phytochrome domain has recently been identified in a cyanobacterial HK, integrating both light and ethylene responses ${ }^{65,66}$. These discoveries thus provide progressively strong arguments leading to the hypothesis that ethylene, more than strictly a plant hormone, would undoubtedly be one of the oldest molecules of intra- and inter-species communication that appeared on Earth, orchestrating not only developmental programs but also biotic interactions between many organisms ${ }^{67}$.

A second well-known eukaryotic HK group encompasses CHASE (cyclases/histidine kinases associated sensing extracellular) ${ }^{68,69}$ domain-containing HKs (CHASE-HKs) (Table 1). To date, most of the members belonging to this group have been characterized in plants as cytokinin receptors ${ }^{62,70}$. Cytokinins correspond to another family of prominent phytohormones involved in many developmental processes in plants, including cell division, embryogenesis, vascular tissue development, and root architecture ${ }^{71}$. The hormone is perceived by this type of transmembrane $\mathrm{HK}$ through the $\mathrm{N}$-terminal region that comprises an extracellular loop ${ }^{70,72}$. More precisely, some crucial residues have been identified within the CHASE sequence to be essential for the binding of the hormones ${ }^{70,72,73}$. As initially postulated for ethylene, cytokinin signal transduction pathways were presumed to be found exclusively in plants ${ }^{74}$. However, these hormones have recently been the subject of very interesting advances that suggest a broader occurrence in the tree of life, notably in eubacteria ${ }^{75}$ and eukaryotic microorganisms ${ }^{62}$. It has been experimentally shown that a bacterial CHASE-HK senses cytokinin, highlighting the importance of HK-cytokinin interactions in inter-kingdom communication ${ }^{75}$. In addition, several genes encoding CHASE-HKs were unearthed in the past two years by browsing the genomes of various non-plant eukaryotic clades $^{61-64}$. These include, for example, some early diverging fungi, brown algae, and diatoms. Although these latter homologs have not been functionally characterized to date, the phylogenetic distribution of CHASE-HKs within the various eukaryotic clades suggests an unexpected and broad involvement of cytokinins and their HK receptors in the regulation of various physiological processes of eukaryotic organisms and interspecies interactions ${ }^{62}$

A third group of eukaryotic HKs involves transmembrane receptors that have been reported to be involved mostly in osmosensing $^{47,49}$. The first members of this group were characterized at the beginning of the 1990s in yeast (referred to as fungal group VI of HKs) and a few years later in plants (referred to as AHK1) (Table 1). In Saccharomyces cells, these receptors are known to allow the yeast to respond and adapt to osmotic and (to a lesser extent) oxidant stresses ${ }^{53,76}$. In Arabidopsis, the TCS controlled by AHK1 was reported to perceive water stress and to initiate histidine-to-aspartate phosphotransfer circuitry for seed desiccation and vegetative stress tolerances ${ }^{47,77-87}$. From a structural perspective, these fungal and plant osmosensors include two large hydrophobic transmembrane helices that border a roughly 300-amino acid extracellular loop predicted to fold mostly into large helices and small sheets, recently identified as a Cache domain ${ }^{36}$. Pioneering studies on this type of receptor demonstrated that expression of plant AHK1 genes can complement the lack of the unique and essential fungal group VI HK gene in yeast, indicating that plant and yeast putative osmosensors have common functional features and origins ${ }^{47,78}$. Interestingly, however, recent genome-wide analyses suggested that these structural and functional similarities rely on an evolutionary convergence process rather than a common archetypal system inherited in both fungi and plants ${ }^{64}$.

Another well-known group of HK-type receptors widely found in many clades of the eukaryotic domain is phytochromes ${ }^{88,89}$. Phytochromes consist of photo-switchable red/far-red photoreceptors that likely evolved in cyanobacteria prior to being transferred to some eukaryotic lineages ${ }^{90,91}$ (Table 1). In both 
Table 1. Some important groups of eukaryotic histidine kinases (HKs), their known input signals, and their output responses.

\begin{tabular}{|c|c|c|c|c|c|}
\hline HK group & Structure & $\begin{array}{l}\text { Presence in } \\
\text { eukaryotes }\end{array}$ & Input signal & Output response & References \\
\hline $\begin{array}{l}\text { Ethylene } \\
\text { receptors }\end{array}$ & 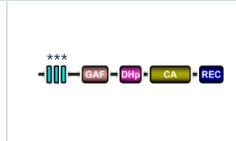 & $\begin{array}{l}\text { Plants, Algae, } \\
\text { Fungi, Amoebae, }\end{array}$ & Ethylene & $\begin{array}{l}\text { Plants: seed germination, } \\
\text { leaf senescence, fruit } \\
\text { ripening, defenses to } \\
\text { pathogens }\end{array}$ & $\begin{array}{l}\text { Ju et al., } 2015^{60} \\
\text { Hérivaux et al., } 2017^{61} \\
\text { Kabbara et al., } 2019^{64}\end{array}$ \\
\hline CHASE-HK & 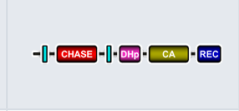 & $\begin{array}{l}\text { Plants, Algae, } \\
\text { Fungi, Amoebae, }\end{array}$ & Cytokinins & $\begin{array}{l}\text { Plants: cell division, } \\
\text { embryogenesis, vascular } \\
\text { tissue development }\end{array}$ & $\begin{array}{l}\text { Kaltenegger et al., } 2018^{74} \\
\text { Hérivaux et al., } 2017^{61}\end{array}$ \\
\hline $\begin{array}{l}\text { AHK1/Fungal } \\
\text { group VI }\end{array}$ & 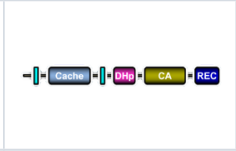 & Plants, Algae, Fungi & $\begin{array}{l}\text { Osmostress Oxidant } \\
\text { stress }\end{array}$ & $\begin{array}{l}\text { Plants: seed desiccation, } \\
\text { vegetative stress tolerances } \\
\text { Fungi: osmotic and oxidant } \\
\text { adaptation }\end{array}$ & $\begin{array}{l}\text { Defosse et al., } 2015^{53} \\
\text { Nongpiur et al., } 2019^{87}\end{array}$ \\
\hline Phytochromes & 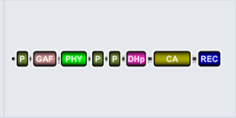 & $\begin{array}{l}\text { Plants, Algae, } \\
\text { Fungi, Amoebae, }\end{array}$ & Red/far red light & $\begin{array}{l}\text { Plants: phototropism } \\
\text { Fungi: vegetative growth, } \\
\text { sexual reproduction }\end{array}$ & $\begin{array}{l}\text { Rensing et al., } 2016^{88} \\
\text { Yu and Fischer, } 2019^{89}\end{array}$ \\
\hline CKI1 & -ロ——- Ш & Plants & Cytokinins? & $\begin{array}{l}\text { Development of female } \\
\text { gametophyte }\end{array}$ & $\begin{array}{l}\text { Yuan et al., } 2016^{92} \\
\text { Liu et al., } 2017^{93} \\
\text { Yuan et al., } 2018^{94}\end{array}$ \\
\hline CKI2/AHK5 & 一 & Plants & $?$ & $\begin{array}{l}\text { Stress-induced stomatal } \\
\text { closure, salt sensitivity, and } \\
\text { resistance against microbial } \\
\text { infection }\end{array}$ & $\begin{array}{l}\text { Pham et al., } 2012^{95} \\
\text { Mira-Rodado et al., } 2012^{96} \\
\text { Bauer et al., } 2013^{97}\end{array}$ \\
\hline Fungal group III & - & Fungi, Amoebae & Osmostress & $\begin{array}{l}\text { Fungi: oxidant adaptation, } \\
\text { development, virulence }\end{array}$ & $\begin{array}{l}\text { Defosse et al., } 2015^{53} \\
\text { Hérivaux et al., } 2016^{54} \\
\text { Kabbara et al., } 2019\end{array}$ \\
\hline Fungal group $X$ & - & $\begin{array}{l}\text { Fungi, Algae, } \\
\text { Amoebae }\end{array}$ & Oxidant stress? & $\begin{array}{l}\text { Fungi: oxidant adaptation, } \\
\text { development, virulence }\end{array}$ & $\begin{array}{l}\text { Defosse et al., } 2015^{53} \\
\text { Hérivaux et al., } 2016^{54} \\
\text { Kabbara et al., } 2019^{64}\end{array}$ \\
\hline $\begin{array}{l}\text { KEY } \\
\text { DHp : Dimerization his } \\
\text { phosphodiesterases- } \\
\text { D: Transmembrane R } \\
\text { translocator protein-S } \\
\text { Phosphatases }\end{array}$ & $\begin{array}{l}\text { tidine phosphotransfe } \\
\text { Adenylyl cyclases-Fhl } \\
\text { egion Cache : Calciur } \\
\text { ingle-minded protein } \\
\text { d: Serine/Threonine K }\end{array}$ & 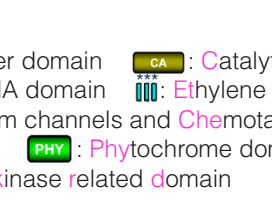 & $\begin{array}{l}\text { tic ATP-binding domain } \\
\text { Binding Domain CHASE: } \\
\text { axis receptors domain } \mathbf{P} \\
\text { main } \mathbf{H} \text { : Histidine kinase }\end{array}$ & $\begin{array}{l}\text { REC : Receiver domain GAF : cC } \\
\text { : Cyclases/Histidine kinases Assoc } \\
\text { : Period circadian protein-Aryl hy } \\
\text { es-Adenylate cyclases-Methyl acc }\end{array}$ & $\begin{array}{l}\text { fiated Sensing Extracellular } \\
\text { drocarbon receptor nuclear } \\
\text { epting proteins and }\end{array}$ \\
\hline
\end{tabular}

plants and fungi, they have been demonstrated to be involved in a wide range of physiological processes ${ }^{88,89}$. Importantly, phytochrome sequences from early diverging plants, as fungal phytochromes, display all conserved amino acid residues for HK activity. In contrast, phytochromes from higher plants commonly contain HK-like domains that instead display Ser/Thr kinase activity, suggesting a structural evolution of these receptors in flowering plants toward other non-TCS output domains ${ }^{98}$. Some recent genome-wide analyses-and, in some cases, functional characterization studies-demonstrated that phytochromes also occur in green and brown algae, diatoms, and amoebae $^{63}$.

There are also other important groups of eukaryotic HKs that have been deeply studied in recent years. These include, for instance, two plant-specific groups: CKI1, which is involved in female gametophyte development ${ }^{92-94}$, and the CKI2/AHK5, which was recently shown to govern the stress-induced stomatal closure, salt sensitivity, and resistance against microbial infection in Arabidopsis ${ }^{95-97}$ (Table 1). Their precise input signals remain unknown. Finally, recent classification of HKs in fungi revealed that these sensing proteins could be categorized into 16 groups $^{64}$; among these, groups III and $\mathrm{X}$ seem to play important roles in stress adaptation, morphogenesis, and virulence $^{53,54}$ (Table 1).

\section{Conclusions}

Sequence information is available for a large number of $\mathrm{HK}$ sensor domains, enabling identification of abundantly populated fold families. A relatively small number of common sensor domains appear across all domains of life, although their abundance is strongly skewed in different organisms. Unfortunately, sequences and fold families often provide little information about ligands or physical stimuli (or both) detected by individual domains if experiences with bacterial HKs are generalizable.

Although studies of bacterial sensing have focused on a small number of structural folds such as Cache and four-helix bundle domains ${ }^{99}$, it is sobering to note that the largest class of bacterial HKs, the prototypical HKs with periplasmic sensing domains, contain 50 to 300 residue-sensing domains that bear no sequence similarity to domains of known folds or functions ${ }^{100}$. 
Even when folds are identifiable, a similar fold can bind many different types of ligands and conversely the same ligand can be bound by domains of different folds in different proteins. Furthermore, even in extensively studied bacterial TCSs where a general stimulus such as cell wall stress is known, the exact molecule or physical parameter sensed by the HK often remains undetermined. Even for some extensively characterized Escherichia coli TCSs, where investigative tools include robust genetics and atomic-resolution three-dimensional structures, specific stimuli remain unidentified. The problem of identifying input stimuli becomes even more complex when multiple sensor kinases or heterodimeric kinases (or both) are integrated into pathways such as the LadS/GacS/RetS/PA1611 system in which interactions among four $\mathrm{HKs}$ regulate biofilm formation in Pseudomonas aeruginosa ${ }^{101-103}$. In this system, the phosphorelay between HKs LadS and GacS is inhibited by RetS-GacS heterodimer formation which is further regulated by interactions between RetS and hybrid HK PA1611.

Remarkably, in plants, most TCSs are characterized with regard to the input stimuli and output responses. This is not true for TCSs of fungi and amoeba, and even less is known about TCSs of archaea. Although genomic analyses are a powerful tool for initial identification, experimental strategies will likely be required to drive discovery of system inputs. Recently, a previously uncharacterized Shewanella oneidensis HK was found to sense $\mathrm{pH}$ in a high-throughput screen of seven different $S$. oneidensis TCSs, using engineered RRs with $S$. oneidensis
REC domains linked to a heterologous DNA-binding domain paired with a cognate reporter gene in $E$. $\operatorname{coli}^{16}$. To the extent that heterologous proteins are functional, synthetic biology approaches such as this promise to provide a powerful strategy for identification of sensory inputs.

Two-component signaling provides a versatile molecular mechanism for stimulus-response coupling, and TCS protein architecture potentially allows an almost limitless range of inputs and outputs. Indeed, enough of the more than 300,000 $\mathrm{TCSs}^{28}$ have been characterized to conclude that bacteria use His-Asp phosphotransfer for almost all categories of signal transduction needs. This does not appear to occur in other domains of life where regulatory systems involving Ser/Thr and Tyr phosphorylation abound. Given the great diversity of sensing and responses in bacterial TCSs, it is curious that archaeal and eukaryotic TCSs appear to have been evolved for a narrower range of functions.

\section{Abbreviations}

Cache, calcium channels and chemotaxis receptors; CHASE, cyclases/histidine kinases associated sensing extracellular; EtBD, ethylene-binding domain; ETR, ethylene receptor; GAF, cGMP-specific phosphodiesterases-adenylyl cyclases-FhlA; HK, histidine kinase; PAS, period circadian protein-Aryl hydrocarbon receptor nuclear translocator protein-single-minded protein; PDC, PhoQ-DcuS-CitA; REC, receiver; RR, response regulator; TCS, two-component system
1. F Fuhs SR, Hunter T: pHisphorylation: The emergence of histidine phosphorylation as a reversible regulatory modification. Curr Opin Cell Biol. 2017; 45: 8-16.

PubMed Abstract | Publisher Full Text | Free Full Text | F1000 Recommendation

2. F Adam K, Hunter T: Histidine kinases and the missing phosphoproteome from prokaryotes to eukaryotes. Lab Invest. 2018; 98(2): 233-47.

PubMed Abstract | Publisher Full Text | Free Full Text | F1000 Recommendation

3. Cai X, Srivastava S, Surindran S, et al.: Regulation of the epithelial $\mathrm{Ca}^{2+}$ channel TRPV 5 by reversible histidine phosphorylation mediated by NDPK-B and PHPT1. Mol Biol Cell. 2014; 25(8): 1244-50.

PubMed Abstract | Publisher Full Text | Free Full Text

4. Fuhs SR, Meisenhelder J, Aslanian A, et al.: Monoclonal 1- and 3Phosphohistidine Antibodies: New Tools to Study Histidine Phosphorylation. Cell. 2015; 162(1): 198-210.

PubMed Abstract | Publisher Full Text | Free Full Text

5. Panda S, Srivastava S, Li Z, et al:: Identification of PGAM5 as a Mammalian Protein Histidine Phosphatase that Plays a Central Role to Negatively Regulate CD4+ T Cells. Mol Cell. 2016; 63(3): 457-69. PubMed Abstract | Publisher Full Text | Free Full Text

6. F Srivastava S, Li Z, Soomro I, et al.: Regulation of $\mathrm{K}_{\mathrm{ATP}}$ Channel Trafficking in Pancreatic $\beta$-Cells by Protein Histidine Phosphorylation. Diabetes. 2018; 67(5): 849-60.

PubMed Abstract | Publisher Full Text | Free Full Text | F1000 Recommendation

7. F Hindupur SK, Colombi M, Fuhs SR, et al:: The protein histidine phosphatase LHPP is a tumour suppressor. Nature. 2018; 555(7698): 678-82. PubMed Abstract | Publisher Full Text | Free Full Text | F1000 Recommendation

8. Bem AE, Velikova N, Pellicer MT, et al:: Bacterial Histidine Kinases as Novel Antibacterial Drug Targets. ACS Chem Biol. 2014; 10(1): 213-24. PubMed Abstract | Publisher Full Text

9. Hussain R, Harding SE, Hughes CS, et al:: Purification of bacterial membrane sensor kinases and biophysical methods for determination of their ligand and inhibitor interactions. Biochem Soc Trans. 2016; 44(3): 810-23. PubMed Abstract | Publisher Full Text | Free Full Text

10. F Tiwari S, Jamal SB, Hassan SS, et al:: Two-Component Signal Transduction Systems of Pathogenic Bacteria As Targets for Antimicrobial Therapy: An Overview. Front Microbiol. 2017; 8: 1878.

PubMed Abstract | Publisher Full Text | Free Full Text | F1000 Recommendation

11. F Utsumi R: Bacterial signal transduction networks via connectors and development of the inhibitors as alternative antibiotics. Biosci Biotechnol Biochem. 2017; 81(9): 1663-9.

PubMed Abstract | Publisher Full Text | F1000 Recommendation

12. F Cardona ST, Choy M, Hogan AM: Essential Two-Component Systems Regulating Cell Envelope Functions: Opportunities for Novel Antibiotic Therapies. J Membr Biol. 2018; 251(1): 75-89. PubMed Abstract | Publisher Full Text | F1000 Recommendation

13. Wolf $D$, Mascher $T$ : The applied side of antimicrobial peptide-inducible promoters from Firmicutes bacteria: Expression systems and whole-cel biosensors. Appl Microbiol Biotechnol. 2016; 100(11): 4817-29. PubMed Abstract | Publisher Full Text

14. Ravikumar S, Baylon MG, Park SJ, et al.: Engineered microbial biosensors based on bacterial two-component systems as synthetic biotechnology platforms in bioremediation and biorefinery. Microb Cell Fact. 2017; 16(1): 62. PubMed Abstract | Publisher Full Text | Free Full Text

15. F Jayaraman P, Holowko MB, Yeoh JW, et al:: Repurposing a Two-Component System-Based Biosensor for the Killing of Vibrio cholerae. ACS Synth Biol. 2017; 6(7): 1403-15.

PubMed Abstract | Publisher Full Text | F1000 Recommendation

16. F Schmidl SR, Ekness F, Sofjan K, et al.: Rewiring bacterial two-component systems by modular DNA-binding domain swapping. Nat Chem Biol. 2019; 15(7): 690-8.

PubMed Abstract | Publisher Full Text | F1000 Recommendation

17. Ganesh I, Ravikumar S, Yoo IK, et al.: Construction of malate-sensing 
Escherichia coli by introduction of a novel chimeric two-component system Bioprocess Biosyst Eng. 2015; 38(4): 797-804.

PubMed Abstract | Publisher Full Text

18. Jung $\mathrm{K}$, Fabiani $\mathrm{F}$, Hoyer $\mathrm{E}$, et al.: Bacterial transmembrane signalling systems and their engineering for biosensing. Open Biol. 2018; 8(4): pii: 180023. PubMed Abstract | Publisher Full Text | Free Full Text

19. F Ravikumar S, David Y, Park SJ, et al:: A Chimeric Two-Componen Regulatory System-Based Escherichia coli Biosensor Engineered to Detect Glutamate. Appl Biochem Biotechnol. 2018; 186(2): 335-49. PubMed Abstract | Publisher Full Text | F1000 Recommendation

20. F Cormann KU, Baumgart M, Bott M: Structure-Based Design of Versatile Biosensors for Small Molecules Based on the PAS Domain of a Thermophilic Histidine Kinase. ACS Synth Biol. 2018; 7(12): 2888-97. PubMed Abstract | Publisher Full Text | F1000 Recommendation

21. F Park DM, Taffet MJ: Combinatorial Sensor Design in Caulobacter crescentus for Selective Environmental Uranium Detection. ACS Synth Biol. 2019; 8(4): 807-17.

PubMed Abstract | Publisher Full Text | F1000 Recommendation

22. Stock AM, Robinson VL, Goudreau PN: Two-Component Signal Transduction. Annu Rev Biochem. 2000; 69: 183-215.

PubMed Abstract | Publisher Full Tex

23. F Jacob-Dubuisson $\mathrm{F}$, Mechaly A, Betton JM, et al:: Structural insights into the signalling mechanisms of two-component systems. Nat Rev Microbiol. 2018; 16(10): 585-93.

PubMed Abstract | Publisher Full Text | F1000 Recommendation

24. Galperin MY: Diversity of structure and function of response regulator output domains. Curr Opin Microbiol. 2010; 13(2): 150-9.

PubMed Abstract | Publisher Full Text | Free Full Text

25. Gao R, Bouillet S, Stock AM: Structural basis of response regulator function. Annu Rev Microbiol. 2019; 73: 175-197.

PubMed Abstract | Publisher Full Tex

26. Appleby JL, Parkinson JS, Bourret RB: Signal Transduction via the Multi-Step Phosphorelay: Not Necessarily a Road Less Traveled. Cell. 1996; 86(6): 845-8. PubMed Abstract | Publisher Full Text

27. Alvarez AF, Barba-Ostria $\mathrm{C}$, Silva-Jiménez $\mathrm{H}$ et al: Organization and mode of action of two component system signaling circuits from the various kingdoms of life. Environ Microbiol. 2016; 18(10): 3210-26. PubMed Abstract | Publisher Full Text

28. F El-Gebali S, Mistry J, Bateman A, et al:: The Pfam protein families database in 2019. Nucleic Acids Res. 2019; 47(D1): D427-D432.

PubMed Abstract | Publisher Full Text | Free Full Text | F1000 Recommendation

29. Grebe TW, Stock JB: The histidine protein kinase superfamily. Adv Microb Physiol. 1999; 41: 139-227.

PubMed Abstract | Publisher Full Text

30. Wuichet K, Cantwell BJ, Zhulin IB: Evolution and phyletic distribution of twocomponent signal transduction systems. Curr Opin Microbiol. 2010; 13(2): 219-25. PubMed Abstract | Publisher Full Text | Free Full Text

31. Esser D, Hoffmann L, Pham TK, et al.: Protein phosphorylation and its role in archaeal signal transduction. FEMS Microbiol Rev. 2016; 40(5): 625-47. PubMed Abstract | Publisher Full Text | Free Full Text

32. F Galperin MY, Makarova KS, Wolf YI, et al.: Phyletic Distribution and ineage-Specific Domain Architectures of Archaeal Two-Component Signal Transduction Systems. J Bacteriol. 2018; 200(7): pii: e00681-17. PubMed Abstract | Publisher Full Text | Free Full Text | F1000 Recommendation

33. F Ortega Á, Zhulin IB, Krell T: Sensory Repertoire of Bacterial Chemoreceptors. Microbiol Mol Biol Rev. 2017; 81(4): pii: e00033-17. PubMed Abstract | Publisher Full Text | Free Full Text | F1000 Recommendation

34. Anantharaman V, Aravind L: Cache - a signaling domain common to anima $\mathrm{Ca}^{2+}$-channel subunits and a class of prokaryotic chemotaxis receptors. Trends Biochem Sci. 2000; 25(11): 535-7.

PubMed Abstract | Publisher Full Tex

35. Zhang Z, Hendrickson WA: Structural characterization of the predominant family of histidine kinase sensor domains. J Mol Biol. 2010; 400(3): 335-53. PubMed Abstract | Publisher Full Text | Free Full Text

36. Upadhyay AA, Fleetwood AD, Adebali O, et al.: Cache Domains That are Homologous to, but Different from PAS Domains Comprise the Largest Superfamily of Extracellular Sensors in Prokaryotes. PLoS Comput Biol. 2016; 12(4): e1004862.

PubMed Abstract | Publisher Full Text | Free Full Text

37. Rudolph J, Tolliday N, Schmitt C, et al:: Phosphorylation in halobacterial signal transduction. EMBO J 1995; 14(17): 4249-57. PubMed Abstract | Publisher Full Text | Free Full Text

38. Salah Ud-Din AIM, Roujeinikova A: Methyl-accepting chemotaxis proteins: a core sensing element in prokaryotes and archaea. Cell Mol Life Sci. 2017; 74(18): 3293-303.

PubMed Abstract | Publisher Full Tex

39. Klare JP, Bordignon E, Engelhard M, et al:: Transmembrane signal transduction in archaeal phototaxis: the sensory rhodopsin II-transducer complex studied by electron paramagnetic resonance spectroscopy. Eur J Cell Biol. 2011; 90(9): 731-9.

PubMed Abstract | Publisher Full Text
40. Inoue K, Tsukamoto $\mathrm{T}$, Sudo $\mathrm{Y}$ : Molecular and evolutionary aspects of microbial sensory rhodopsins. Biochim Biophys Acta. 2014; 1837(5): 562-77.

PubMed Abstract | Publisher Full Text

41. Najnin T, Siddiqui KS, Taha T, et al:: Characterization of a temperatureresponsive two component regulatory system from the Antarctic archaeon, Methanococcoides burtonii. Sci Rep. 2016; 6: 24278. PubMed Abstract | Publisher Full Text | Free Full Text

42. Li J, Zheng X, Guo X, et al:: Characterization of an archaeal two-component system that regulates methanogenesis in Methanosaeta harundinacea. PLOS One. 2014; 9(4): e95502.

PubMed Abstract | Publisher Full Text | Free Full Text

43. Molitor B, Stassen M, Modi A, et al:: A heme-based redox sensor in the methanogenic archaeon Methanosarcina acetivorans. J Biol Chem. 2013; 288(25): 18458-72.

PubMed Abstract | Publisher Full Text | Free Full Tex

44. F Fiege K, Frankenberg-Dinkel N: Thiol-based redox sensing in the methyltransferase associated sensor kinase RdmS in Methanosarcin acetivorans. Environ Microbiol. 2019; 21(5): 1597-610.

PubMed Abstract | Publisher Full Text | F1000 Recommendation

45. Chang C, Kwok SF, Bleecker AB, et al:: Arabidopsis ethylene-response gene ETR1: similarity of product to two-component regulators. Science. 1993; 262(5133): 539-44

PubMed Abstract | Publisher Full Text

46. Kakimoto $\mathrm{T}$ : CKI1, a histidine kinase homolog implicated in cytokinin signa transduction. Science. 1996; 274(5289): 982-5. PubMled Abstract | Publisher Full Text

47. Urao T, Yakubov B, Satoh R, et al: A transmembrane hybrid-type histidine kinase in Arabidopsis functions as an osmosensor. Plant Cell. 1999; 11(9): $1743-54$

PubMed Abstract | Publisher Full Text | Free Full Text

48. $\mathrm{F}$ Inoue $\mathrm{T}$, Higuchi M, Hashimoto $\mathrm{Y}$, et al:: Identification of CRE1 as a cytokinin receptor from Arabidopsis. Nature. 2001; 409(6823): 1060-3. PubMed Abstract | Publisher Full Text | F1000 Recommendation

49. Wang N, Shaulsky G, Escalante R, et al.: A two-component histidine kinase gene that functions in Dictyostelium development. EMBO J.1996; 15(15): 3890-8. PubMed Abstract | Publisher Full Text | Free Full Text

50. Schuster SC, Noegel AA, Oehme F, et al.: The hybrid histidine kinase DokA is part of the osmotic response system of Dictyostelium. EMBO J. 1996; 15(15): $3880-9$.

PubMed Abstract | Publisher Full Text | Free Full Text

51. F Singleton CK, Zinda MJ, Mykytka B, et al:: The histidine kinase dhkC regulates the choice between migrating slugs and terminal differentiation in Dictyostelium discoideum. Dev Biol. 1998; 203(2): 345-57. PubMed Abstract | Publisher Full Text | F1000 Recommendation

52. Zinda MJ, Singleton CK: The hybrid histidine kinase dhkB regulates spore germination in Dictyostelium discoideum. Dev Biol. 1998; 196(2): 171-83. PubMed Abstract | Publisher Full Text

53. Defosse TA, Sharma A, Mondal AK, et al:: Hybrid histidine kinases in pathogenic ungi. Mol Microbiol. 2015; 95(6): 914-24.

PubMed Abstract| Pu

54. Hérivaux A, So YS, Gastebois A, et al.: Major Sensing Proteins in Pathogenic Fungi: The Hybrid Histidine Kinase Family. PLoS Pathog. 2016; 12(7): e1005683. PubMed Abstract | Publisher Full Text | Free Full Text

55. Schaller GE, Shiu SH, Armitage JP: Two-component systems and their cooption for eukaryotic signal transduction. Curr Biol. 2011; 21(9): R320-R330. PubMed Abstract | Publisher Full Text

56. Gallie DR: Ethylene receptors in plants - why so much complexity? F1000Prime Rep. 2015; 7: 39

PubMed Abstract | Publisher Full Text | Free Full Text

57. Abeles F, Morgan P, Saltveit MJ: Ethylene in Plant Biology. 2 edn, Academic Press. 1992 Reference Source

58. Wang W, Esch JJ, Shiu SH, et al:: Identification of important regions for ethylene binding and signaling in the transmembrane domain of the ETR1 ethylene receptor of Arabidopsis. Plant Cell. 2006; 18(12): 3429-42. PubMed Abstract | Publisher Full Text | Free Full Text

59. Mount SM, Chang C: Evidence for a plastid origin of plant ethylene receptor genes. Plant Physiol. 2002; 130(1): 10-4. PubMed Abstract | Publisher Full Text | Free Full Text

60. F Ju C, Van de Poel B, Cooper ED, et al.: Conservation of ethylene as a plant hormone over $\mathbf{4 5 0}$ million years of evolution. Nat Plants. 2015; 1: 14004 PubMed Abstract | Publisher Full Text | F1000 Recommendation

61. Hérivaux A, Dugé de Bernonville T, Roux C, et al:: The Identification of Phytohormone Receptor Homologs in Early Diverging Fungi Suggests a Role for Plant Sensing in Land Colonization by Fungi. mBio. 2017; 8(1): pii: e01739-16. PublMed Abstract | Publisher Full Text | Free Full Text

62. Kabbara S, Schmülling T, Papon N: CHASEing Cytokinin Receptors in Plants, Bacteria, Fungi, and Beyond. Trends Plant Sci. 2018; 23(3): 179-81. PubMed Abstract | Publisher Full Text

63. Kabbara S, Bidon B, Kilani J, et al: Megaviruses: An involvement in phytohormone receptor gene transfer in brown algae? Gene. 2019; 704: 149-51. PubMled Abstract | Publisher Full Text 
64. Kabbara S, Hérivaux A, Dugé de Bernonville T, et al.: Diversity and Evolution of Sensor Histidine Kinases in Eukaryotes. Genome Biol Evol. 2019; 11(1): 86-108. PubMed Abstract | Publisher Full Text | Free Full Text

65. Lacey RF, Binder BM: Ethylene Regulates the Physiology of the Cyanobacterium Synechocystis sp. PCC 6803 via an Ethylene Receptor. Plant Physiol. 2016; 171(4): 2798-809.

PubMed Abstract | Publisher Full Text | Free Full Text

66. F Lacey RF, Allen CJ, Bakshi A, et al:: Ethylene causes transcriptomic changes in Synechocystis during phototaxis. Plant Direct. 2018; 2(3): e00048. PubMed Abstract | Publisher Full Text | Free Full Text | F1000 Recommendation

67. Papon N, Binder BM: An Evolutionary Perspective on Ethylene Sensing in Microorganisms. Trends Microbiol. 2019; 27(3): 193-6. PubMed Abstract | Publisher Full Text

68. Anantharaman V, Aravind L: The CHASE domain: a predicted ligand-binding module in plant cytokinin receptors and other eukaryotic and bacterial receptors. Trends Biochem Sci. 2001; 26(10): 579-82. PubMed Abstract | Publisher Full Tex

69. Mougel C, Zhulin IB: CHASE: an extracellular sensing domain common to transmembrane receptors from prokaryotes, lower eukaryotes and plants. Trends Biochem Sci. 2001; 26(10): 582-4.

PubMed Abstract | Publisher Full Text

70. Gruhn N, Halawa M, Snel B, et al.: A subfamily of putative cytokinin receptors is revealed by an analysis of the evolution of the two-component signaling system of plants. Plant Physiol. 2014; 165(1): 227-37. PubMed Abstract | Publisher Full Text | Free Full Text

71. Kieber JJ, Schaller GE: Cytokinins. Arabidopsis Book. 2014; 12: e0168. PubMed Abstract | Publisher Full Text | Free Full Text

72. Hothorn M, Dabi T, Chory J: Structural basis for cytokinin recognition by Arabidopsis thaliana histidine kinase 4. Nat Chem Biol. 2011; 7(11): 766-8. PubMed Abstract | Publisher Full Text | Free Full Text

73. Daudu D, Kisiala A, Werner Ribeiro C, et al:: Setting-up a fast and reliable cytokinin biosensor based on a plant histidine kinase receptor expressed in Saccharomyces cerevisiae. J Biotechnol. 2019; 289: 103-11. PubMed Abstract | Publisher Full Text

74. F Kaltenegger E, Leng S, Heyl A: The effects of repeated whole genome duplication events on the evolution of cytokinin signaling pathway. BMC Evol Biol. 2018; 18(1): 76.

PubMed Abstract | Publisher Full Text | Free Full Text | F1000 Recommendation

75. F Wang FF, Cheng ST, Wu Y, et al:: A Bacterial Receptor PcrK Senses the Plant Hormone Cytokinin to Promote Adaptation to Oxidative Stress. Cell Rep. 2017; 21(10): 2940-51.

PubMed Abstract | Publisher Full Text | F1000 Recommendation

76. Hérivaux A, Lavín JL de Bernonville TD, et al: Progressive loss of hybrid histidine kinase genes during the evolution of budding yeasts (Saccharomycotina). Curr Genet. 2018; 64(4): 841-51. PubMed Abstract | Publisher Full Text

77. Chefdor F, Bénédetti H, Depierreux C, et al:: Osmotic stress sensing in Populus: components identification of a phosphorelay system. FEBS Lett. 2006; 580 (1): $77-81$.

PubMed Abstract | Publisher Full Text

78. Tran LS, Urao T, Qin F, et al:: Functional analysis of AHK1/ATHK1 and cytokinin receptor histidine kinases in response to abscisic acid, drought, and salt stress in Arabidopsis. Proc Natl Acad Sci U S A. 2007; 104(51): 20623-8. PubMed Abstract | Publisher Full Text | Free Full Text

79. Wohlbach DJ, Quirino BF, Sussman MR: Analysis of the Arabidopsis histidine kinase ATHK1 reveals a connection between vegetative osmotic stress sensing and seed maturation. Plant Cell. 2008; 20(4): 1101-17. PubMed Abstract | Publisher Full Text | Free Full Text

80. Bertheau L, Chefdor F, Guirimand G, et al.: Identification of five B-type response regulators as members of a multistep phosphorelay system interacting with histidine-containing phosphotransfer partners of Populus osmosensor. BMC Plant Biol. 2012; 12: 241.

PubMed Abstract | Publisher Full Text | Free Full Text

81. Héricourt F, Chefdor F, Bertheau L, et al:: Characterization of histidine-aspartate kinase HK1 and identification of histidine phosphotransfer proteins as potential partners in a Populus multistep phosphorelay. Physiol Plant. 2013, 149(2): 188-99. PubMed Abstract | Publisher Full Tex

82. F Kumar MN, Jane WN, Verslues PE: Role of the putative osmosensor Arabidopsis histidine kinase 1 in dehydration avoidance and low-water-potential response. Plant Physiol. 2013; 161(2): 942-53.

PubMed Abstract | Publisher Full Text | Free Full Text | F1000 Recommendation

83. Kushwaha HR, Singla-Pareek SL, Pareek A: Putative osmosensor--OsHK3b--a histidine kinase protein from rice shows high structural conservation with its ortholog AtHK1 from Arabidopsis. J Biomol Struct Dyn. 2014; 32(8): 1318-32. PubMed Abstract | Publisher Full Text | Free Full Text
84. Bertheau L, Djeghdir I, Foureau E, et al.: Insights into B-type RR members as signaling partners acting downstream of HPt partners of HK1 in the osmotic stress response in Populus. Plant Physiol Biochem. 2015; 94: 244-52. PubMed Abstract | Publisher Full Text

85. Héricourt F, Chefdor F, Djeghdir I, et al.: Functional Divergence of Poplar Histidine-Aspartate Kinase HK1 Paralogs in Response to Osmotic Stress. Int J Mol Sci. 2016; 17(12): pii: E2061.

PubMed Abstract | Publisher Full Text | Free Full Text

86. F Chefdor F, Héricourt F, Koudounas $\mathrm{K}$, et al:: Highlighting type A RRs as potential regulators of the dkHK1 multi-step phosphorelay pathway in Populus. Plant Sci. 2018; 277: 68-78.

PubMed Abstract | Publisher Full Text | F1000 Recommendation

87. Nongpiur RC, Singla-Pareek SL, Pareek A: The quest for 'osmosensors' in plants. J Exp Bot. 2019; pii: erz263. PubMed Abstract | Publisher Full Tex

88. Rensing SA, Sheerin DJ, Hiltbrunner A: Phytochromes: More Than Meets the Eye. Trends Plant Sci. 2016; 21(7): 543-6. PubMed Abstract | Publisher Full Text

89. F Yu Z, Fischer R: Light sensing and responses in fungi. Nat Rev Microbiol. 2019; 17(1): 25-36. PubMed Abstract | Publisher Full Text | F1000 Recommendation

90. Yeh KC, Wu SH, Murphy JT, et al.: A cyanobacterial phytochrome twocomponent light sensory system. Science. 1997; 277(5331): 1505-8. PubMed Abstract | Publisher Full Text

91. F Rockwell NC, Lagarias JC: Phytochrome diversification in cyanobacteria and eukaryotic algae. Curr Opin Plant Biol. 2017; 37: 87-93. PubMed Abstract | Publisher Full Text | Free Full Text | F1000 Recommendation

92. F Yuan L, Liu Z, Song X, et al:: The CKI1 Histidine Kinase Specifies the Female Gametic Precursor of the Endosperm. Dev Cell. 2016; 37(1): 34-46. PubMed Abstract | Publisher Full Text | F1000 Recommendation

93. F Liu Z, Yuan L, Song X, et al:: AHP2, AHP3, and AHP5 act downstream of CKI1 in Arabidopsis female gametophyte development. J Exp Bot. 2017; 68(13): 3365-73.

PubMed Abstract | Publisher Full Text | Free Full Text | F1000 Recommendation

94. F Yuan L, Liu Z, Song X, et al:: The gymnosperm ortholog of the angiosperm central cell-specification gene CKI1 provides an essential clue to endosperm origin. New Phytol. 2018; 218(4): 1685-96.

PubMed Abstract | Publisher Full Text | F1000 Recommendation

95. Pham J, Desikan R: Modulation of ROS production and hormone levels by AHK5 during abiotic and biotic stress signaling. Plant Signal Behav. 2012; 7(8): 893-7.

PubMed Abstract | Publisher Full Text | Free Full Text

96. Mira-Rodado V, Veerabagu M, Witthöft J, et al:: Identification of two-componen system elements downstream of AHK5 in the stomatal closure response of Arabidopsis thaliana. Plant Signal Behav. 2012; 7(11): 1467-76. PubMed Abstract | Publisher Full Text | Free Full Text

97. Bauer J, Reiss K, Veerabagu M, et al:: Structure-function analysis of Arabidopsis thaliana histidine kinase AHK5 bound to its cognate phosphotransfer protein AHP1. Mol Plant. 2013; 6(3): 959-70.

PubMed Abstract| Publisher Full Text

98. F Li FW, Melkonian M, Rothfels CJ, et al.: Phytochrome diversity in green plants and the origin of canonical plant phytochromes. Nat Commun. 2015; 6: 7852. PubMed Abstract | Publisher Full Text | Free Full Text | F1000 Recommendation

99. Cheung J, Hendrickson WA: Sensor domains of two-component regulatory systems. Curr Opin Microbiol. 2010; 13(2): 116-23. PubMed Abstract | Publisher Full Text | Free Full Text

100. Mascher T, Helmann JD, Unden G: Stimulus perception in bacterial signaltransducing histidine kinases. Microbiol Mol Biol Rev. 2006; 70(4): 910-38. PubMed Abstract | Publisher Full Text | Free Full Text

101. F Goodman AL, Merighi M, Hyodo M, et al:: Direct interaction between sensor kinase proteins mediates acute and chronic disease phenotypes in a bacterial pathogen. Genes Dev. 2009; 23(2): 249-59.

PubMed Abstract | Publisher Full Text | Free Full Text | F1000 Recommendation

102. Chambonnier G, Roux L, Redelberger D, et al: The Hybrid Histidine Kinase LadS Forms a Multicomponent Signal Transduction System with the GacS/GacA Two-Component System in Pseudomonas aeruginosa. PLoS Genet. 2016; 12(5): e1006032.

PubMed Abstract | Publisher Full Text | Free Full Text

103. Bhagirath AY, Pydi SP, Li Y, et al:: Characterization of the Direct Interaction between Hybrid Sensor Kinases PA1611 and RetS That Controls Biofilm Formation and the Type III Secretion System in Pseudomonas aeruginosa. ACS Infect Dis. 2017; 3(2): 162-75.

PubMed Abstract | Publisher Full Tex 


\section{Open Peer Review}

\section{Current Peer Review Status:}

\section{Editorial Note on the Review Process}

Faculty Reviews are review articles written by the prestigious Members of Faculty Opinions. The articles are commissioned and peer reviewed before publication to ensure that the final, published version is comprehensive and accessible. The reviewers who approved the final version are listed with their names and affiliations.

\section{The reviewers who approved this article are:}

\section{Version 1}

\section{Sean Crosson}

Department of Microbiology \& Molecular Genetics, Michigan State University, East Lansing, MI, USA Competing Interests: No competing interests were disclosed.

\section{Jeffrey J. Tabor}

Department of Bioengineering \& Department of Biosciences, Rice University, Houston, TX, USA

Competing Interests: No competing interests were disclosed.

\section{Wei Qian}

State Key Laboratory of Plant Genomics, Institute of Microbiology, Chinese Academy of Sciences, Beijing, China

Competing Interests: No competing interests were disclosed.

The benefits of publishing with F1000Research:

- Your article is published within days, with no editorial bias

- You can publish traditional articles, null/negative results, case reports, data notes and more

- The peer review process is transparent and collaborative

- Your article is indexed in PubMed after passing peer review

- Dedicated customer support at every stage

For pre-submission enquiries, contact research@f1000.com 